\title{
Evaluating the Success of Decentralisation in Facilitating the Inclusion of Rwanda's Marginalised
}

\section{Morag Goodwin ${ }^{1}$}

Accepted: 21 October 2021 / Published online: 18 November 2021

(C) The Author(s) 2021

\begin{abstract}
Decentralisation plays a key role in Rwanda's efforts to overcome the violence and instability of the past by fostering national unity and by bringing governance closer to the people. This paper examines the impact of decentralisation on the feelings of inclusion of Rwanda's most marginalised group, the Batwa. Drawing on a 4-year empirical project, our findings suggest that, despite impressive improvements in the living standards of the poorest and efforts to encourage participation in local decision making, many Twa do not feel included. This suggests that the government has not yet succeeded in creating downward accountability. We attribute this to two factors: continuing economic inequality and poor communication.
\end{abstract}

Keywords Decentralisation · Inclusive development · Rwanda · Batwa · Inequality · Communication

\section{Résumé}

La décentralisation joue un rôle primordial dans les efforts mis en oeuvre par le Rwanda pour surmonter la violence et l'instabilité de son passé, en favorisant l'unité nationale et en rapprochant la gouvernance de son peuple. Cet article étudie l'impact de la décentralisation sur le sentiment d'inclusion du groupe le plus marginalisé du Rwanda, les Batwa. Nos résultats s'appuient sur un projet empirique de quatre ans et suggèrent que, en dépit de l'améliorations remarquable du niveau de vie des populations les plus pauvres et des efforts pour encourager leur participation à la prise de décision locale, de nombreux Twa ne se sentent pas inclus. Cela suggère que le gouvernement n'a pas réussi à créer un système de reddition de comptes vers sa population. Nous attribuons cela à deux facteurs : la persistance des inégalités économiques et une mauvaise communication.

JEL classification 020

Morag Goodwin

m.e.a.goodwin@tilburguniversity.edu

1 Tilburg University, Tilburg, The Netherlands 


\section{Introduction}

In the aftermath of the civil war and genocide that destroyed much of Rwanda's physical and social infrastructure, the new government created a plan to rebuild the country built on two mutually reinforcing pillars: national unity and poverty reduction (NURC 2004). It was explicitly understood that lasting reconciliation could not be achieved without bringing citizens together through shared socioeconomic development (NURC 2016). Key to the realisation of both was good governance. In turn, good governance was to be achieved by decentralisation, which was to foster reconciliation by empowering citizens to hold government to account (NURC 2009). Decentralisation is, thus, a crucial part of Rwanda's plans to overcome the violence of the past and ensure lasting stability (see McDoom 2021; Kimonyo 2015 on the role that the centralisation of authority played in creating the 'perfect storm' of genocide). The regime's commitment to holding government to account via citizenship empowerment makes Rwanda an interesting case for examining the extent to which decentralisation can contribute to achieving inclusive development. If decentralisation is to be able to play a role in overcoming division and sectarianism, those on the receiving end need to feel included. This paper draws on data collected between 2014 and 2018 investigating Batwa socio-marginalisation in Rwanda and on government-produced studies and documents to explore this dynamic from the perspective of Rwanda's most marginalised group, the Twa.

The Twa are the third of Rwanda's three groups and are thought to comprise less than $1 \%$ of the Rwandan population, although accurate figures are not available. They are socially and economically at the margins of Rwandan society. Understood to be descendants of the Pygmy populations of central Africa, the Twa of Rwanda, thus, form part of the larger Batwa population living throughout the Great Lakes Region (Lewis 2000). They were traditionally forest-dwelling hunter gatherers, subject to often extreme marginalisation and negative stereotyping by both cultivators and pastoralists (Vansina, 2001). As Taylor notes, "Twa were perceived as wild, polluting, and disgusting" (Taylor 2011, p. 186). Such sentiments continued into the contemporary era, placing Twa on the social margins of society. At the same time, pressure on land and national policies to protect the remaining rainforests have meant a loss of traditional hunting grounds and, hence, the loss of Twa traditional economic activities. This destruction of their economic way of life and a lack of access to land has forced many to eke out a living as potters and day labourers (Lewis 2000; Ndahinda 2011; ICERD 2016).

The Twa are frequently overlooked in the post-genocidal landscape. Straddling the divide between victim and perpetrator, their place in the post-genocidal set-up is ambiguous. This has led to criticisms that the Twa are invisible in the process of reconciliation (Thompson 2009, p. 316). The project on which this paper is based attempted to give greater visibility to the position of the Twa in the postgenocidal landscape (see also Dietz 2012). While it would be unwise to draw general conclusions for the whole Rwandan population from interviews with Twa, the position of this community as the most marginalised and most economically 
vulnerable within society provides important information on how far down government policies on inclusion and citizen empowerment reach-and hence about the success of, and barriers to, decentralisation efforts.

\section{Methodology}

The data used in this paper was collected between 2014 and 2018. Interviews with members of the Batwa community were conducted in two waves: a pilot study of 24 interviews that allowed us to test and refine the categories ${ }^{1}$ and an additional 65 interviews. The participants were drawn from a cross section of the Batwa community and were selected using purposive sampling on the basis of location, age, gender and level of education. Interviews took place in all districts of the country, including the capital. A third wave of interviews, focus groups and other types of interaction were conducted with strategic actors at the local and national level, such as sector and district leaders, members of parliament, NGOs and other public institutions. This group also included non-Twa members of the same communities. This data was used to triangulate our findings. The interviews were semi-structured interviews based on a conversational format, with the questions as a guide for the interviewer but not a rulebook. The interviews ranged from 2 to $4 \mathrm{~h}$ in duration and were audio recorded; a representative number of interviews were also filmed where the participant gave additional consent to being filmed.

The interviews were conducted by six local researchers with experience of community organisation in Batwa communities as employees of or freelancers with COPORWA. ${ }^{2}$ By using individuals known in the communities to conduct the interviews, and by adopting a private conversational format, we hoped to create the conditions in which individuals felt able to speak freely. The interviews were transcribed by the interviewers and then translated into English. The translated transcripts were checked by bilingual project staff, with a focus on consistency and terminology. The choice for particular translations was discussed within the project and with project stakeholders during the three workshops held in Kigali in February 2014, October 2015 and October 2017. The interviews were analysed using grounded theory (Bentzon et al. 1998; Hammett et al. 2015). On the basis of the pilot interviews, a set of codes were identified, intensively discussed with in-country project stakeholders, refined and then further refined during the main body of analysis. ${ }^{3}$ The initial findings were road tested in four feedback sessions in May and June 2017. These sessions were held in Kibeho/Nyaruguru (Southern Province), Cyanika/Burera (Northern Province), Nyamata/Bugesera (Eastern Province) and Nyange/Ngororero

\footnotetext{
1 This project drew on the methodological approach developed by Wolff and de-Shalit (2007) in which the capability approach of Sen and Nussbaum is modified to develop categories of secure functionings that are used to frame how we understand disadvantage from the perspective of the disadvantaged. Developing categories for the Rwandan context was a key step in our methodology.

${ }^{2}$ Communauté des Potiers du Rwanda /Rwandese Community of Potters. COPORWA is an advocacy organisation for Batwa.

3 Among the codes that emerged were 'voice', 'empowerment', 'nature', 'unfairness', 'identity'.
} 
(Western Province) and were attended by Twa individuals as well as by officials from the sector and district leaderships. The findings were further interrogated during a stakeholder workshop in Kigali in October 2017.

The empirical data drawn on here are contextualised by reference to government policy documents and government-funded studies. These documents help make sense of the data but also form additional material for analysis. A limitation worth noting is the author's restriction to English-language documents.

\section{Decentralisation Policies and Inclusion in Rwanda: Holding Government to Account}

While national unity has been the core principle and goal of the rebuilding process, it was not the only tenet to come out of the Urugwiro process in the immediate aftermath of the genocide. Instead, the goal of reconciliation and rebuilding was to be the creation of "a united, democratic and prosperous country" (NURC 2016, pp. 49-50). The new regime committed itself to poverty reduction as an essential part of achieving reconciliation (NURC 2016, pp. 56-57). Similarly, good governance was identified as essential to achieving national stability. Good governance was equated very early on with decentralisation (NURC 2016, p. 67), based on the idea that unity and reconciliation could only be achieved by both changing the relationship between the governed and those in power and by overcoming a subculture of passive obedience that made the people vulnerable to sectarian manipulation (NURC 2016, p. 69; McDoom 2021). Decentralisation was to bring the government closer to the people and make it easier for them to hold it to account. Decentralisation is also central to the Rwandan vision of economic development. Rwanda's Vision 2020 highlighted it as a tool for the empowerment of citizens and for the realisation of a form of economic development based on self-reliance and dignity (MINECOFIN 2015).

The focus in Rwanda on decentralisation followed a general trend within development theory. The centrality that decentralisation has taken on in past decades in good governance debates stems from the notion that the effective provision of public services is more likely when an empowered citizenry can hold authorities to account, and the belief that this is more easily done at the local level (Booth and Cammack 2013). As such, local institutions can better discern and are more likely to respond to local needs and aspirations. To achieve this, however, what is needed is active community participation in identifying needs and the accountability of leaders to the local community, or downward accountability. Moreover, it is usually necessary to establish special measures, such as community programmes or incentives, in order to convince individuals to engage in constructive collective action. However, as Booth and Cammack note, community participation is often used as a substitute for action on the part of the state (Booth and Cammack 2013, p. 28). For decentralisation to, therefore, be meaningful, it needs to involve a substantial shift of power and resources downwards while at the same time ensuring the necessary downward accountability (Ribot 2002).

Decentralisation is also increasingly linked to the notion of inclusive development. Inclusion in development processes has been embraced by nearly all actors 
within the development sector (Reinders et al. 2019). While the relationship of economic growth to inequality has long been debated, it is now broadly accepted that high levels of inequality inhibit rapid economic growth by creating increased levels of vulnerability and low levels of resilience to shocks (Rodrik 2007). Moreover, it is broadly accepted that growing levels of inequality threaten the peace and stability of a country, with rising levels of inequality matching rising levels of political instability, weakening social cohesion and thus increasing the likelihood of conflict (Reinders et al. 2019; Ansoms 2009). Decentralisation and the opportunities that it creates for local participation and the articulation of local needs, are seen within development theory as an important tool in combating inequality and, thus, in creating social stability. If decentralisation is expected to create the space for inclusive processes, what then should those processes look like?

Gupta et al. locate the concept of inclusive development within development theories as a continuation of a turn to human development within the context of a return to growth in the 2010s (Gupta et al. 2015). The concept brings together concerns with poverty reduction, empowerment, gains in human capital, gendered development, concerns with social capital development, and social protection. Inclusiveness is then best understood as a combination of material, social-relational and psychological well-being (Gough and McGregor 2007). In this understanding, while material well-being refers to an individual's living standards and their access to the assets necessary for them to lead a life that is valuable to them, social-relational well-being consists in how individuals relate to their natural and social environment and are able to live well together. Psychological or cognitive well-being focuses on people's own experiences and knowledge about their lives and relates to their feelings about their ability to achieve things that matter to them. To achieve this broad understanding of inclusiveness, it is necessary to focus resources on the poorest, the most vulnerable and the most marginalised; but it is also necessary to ensure that the knowledge and desires of those targeted for inclusion are taken into account in the development process, whatever forms that takes (Dekker and Pouw 2021). Inclusive development, then, requires participatory mechanisms that are capable of giving voice to those at the bottom and of translating their knowledge and aspirations into policy making. It must take account of power dynamics (Gaventa 2005) visible, hidden and invisible_-and create a feeling of ownership and inclusion in development processes (see VeneKlasen and Miller 2002, p. 55), at the same time as delivering concrete material improvements. Dietz has argued in the context of rural communities in Ghana and Burkina Faso that the poor need to view themselves as agents of their own transformation if pro-poor policies are to be inclusive (Dietz et al. 2013). As such, inclusiveness requires both attention to outcome and to process. Achieving inclusiveness is, thus, a complex governance task, but the emphasis on participation means that local authorities have a key role to play in ensuring that both the processes and outcomes of development meet the needs and desires of all those within their area.

An ambitious decentralisation process was launched in Rwanda in 2000, with the creation of the National Decentralization Policy (amended in 2012) and the formation of the Ministry of Local Government (MINALOC), which was to oversee it. Decentralisation was to take place in three phases (MINALOC 2001; MINALOC 
2004). The first phase of decentralisation (2001-2005) was focused on the creation of the district level and on the necessary legal, institutional and policy reforms, as well as establishing elections for local leaders. The second phase (2006-2010) followed the drastic territorial restructuring of local administration and focused on enhancing the effectiveness of service delivery to communities. In this phase, local administration was completely re-organised and the number of provinces, districts, sectors and cells was slashed, while a new administrative level—the umudugudu (village or neighbourhood) — was created. At the same time, the second phase also aimed to create upward accountability through the introduction of annual performance contracts: Imihigo, under which local leaders were directly accountable to central government for progress in delivering on the yearly action plans drawn up on the basis of the Five Year District Development Plan (NURC 2016). As Chemouni notes, "[d]ecentralization in Rwanda was thus a profound and relatively rapid institutional change: it created new entities, suppressed others, and redrew the boundaries of existing one." (Chemouni 2014, p. 248) To these far-reaching reforms was added the heavily symbolic move to change the names of the main localities across the country. The third phase (2011-2015) was intended to develop "downward accountability linkages between local government leadership and citizens." (MINALOC 2011). The revisions to the decentralisation policy in 2012 placed further emphasis on citizen participation and empowerment (MINALOC 2018a, b).

The decentralisation reforms have created the district as the main actor of local government. Each of the 30 districts is responsible for economic development in their area, including agriculture, tourism and the development of SMEs (small and medium-sized enterprises). They are also responsible for the co-ordination of service delivery, such as health services, education, water and sanitation. At the next level down, the sector is responsible for delivering services to the population, such as administrative documents, data collection and reporting and community mobilisation. The cell, the lowest administrative unit, is involved in community mobilisation and data collection. The village is not an administrative unit but is a forum for grassroots mobilisation and policy communication. To this end, the umudugudu is formed of an elected leadership committee of five members who are to hold regular meetings so that residents can receive information but also discuss issues of concern and raise questions that can be channelled up the chain to local leaders. All in, this represents a dramatic shift of governance capability to the local level. According to government figures, in the 10 years between 2006 and 2017, covering phases 2 and 3, local government income increased from RwF 49.7 billion to RwF 440.3 billion, the vast majority of which came from central government transfers (MINALOC 2018a, b). This represents, according to Chemouni, a genuine effort to empower the districts within the governance structure (Chemouni 2016).

As the government's review of the first three phases notes, Rwanda's approach to decentralisation was to focus on outcomes not form: service delivery and empowerment, not merely on the holding of local elections (MINALOC 2018a, b, p. 96). In addition to regular elections of local leaders across 9 levels of local governance, a range of community activities are intended to provide forums in which citizens can give voice to their ideas and concerns, and through which they can hold local leaders to account. The focus of participation is on weekly meetings at the village level 
(umudugudu) following compulsory work programmes, such as Ubudehe and Umuganda, which serve as the main forum through which citizens receive information and participate in government programmes (MINALOC 2018a, b, p. 58). It is also the forum in which villagers take decisions about who is to benefit from resource delivery programmes, such as Girinka, and participate in national unity initiatives such as Itorero and Ndi Umunyarwanda (NURC 2007). In addition, weekly citizen meetings are also held at the District level (Inteko z'abaturage), in which citizens can make requests or bring complaints (MINALOC 2018a, b).

If the Rwandan model of decentralisation was intended to ensure resource delivery at the local level and enable local accountability, how has it done? By nearly all accounts, service delivery has greatly improved, most notably in education and health care, which is understood by many to have led directly to significant improvements in living conditions for the majority of Rwandans (McKay and Verpoorten 2016; Chemouni 2016, p. 766). ${ }^{4}$ McKay and Verpoorten note that the overall pattern is "of big improvements in health, education, assets, and housing conditions between 2000 and 2010, and of improvements in which rural areas and the poor appear to share equally". (McKay and Verpoorten 2016, p. 118). This assessment is confirmed by governmental survey data which see $78.7 \%$ strongly and $18.9 \%$ somewhat agree that their social well-being has improved as a result of decentralisation; a further $95 \%$ of those surveyed believe that decentralisation has made them economically better off (MINALOC $2018 \mathrm{a}, \mathrm{b}$, p. 34$){ }^{5}$

Similarly, the government's own evaluation of the success of the third phase suggests that citizen participation has significantly improved. ${ }^{6} 91 \%$ of those surveyed for the report reported that they had trust in their local leaders (MINALOC 2018a, b, p. 35). Equally, $90.8 \%$ said that they had access to information on decisions made by local authorities; $62.6 \%$ reported that local authority communication was highly effective, and more than half agreed that decision making was communicated to them in a timely manner (MINALOC 2018a, b, pp. 57-60). In addition to receiving information, over $93 \%$ either strongly or somewhat agreed that local authorities were responsive to grievances raised by ordinary citizens; and $96.8 \%$ report that they are usually or often fair, responsive or sensitive to ordinary citizens' concerns (MINALOC 2018a, b, pp. 43-47). Moreover, more than half (53\%) were confident that they could get redress from local authorities if those authorities failed to deliver on their commitments; and $94 \%$ said that they were able to challenge local authority decision making without fear of retribution (MINALOC 2018a, b, pp. 51-55). On resource distribution, $89.4 \%$ strongly or somewhat agreed that beneficiaries of social

\footnotetext{
4 The poverty reduction data issued by the Rwanda National Institute for Statistics are contested: see FT, Rwanda: where even poverty data must toe Kagame's line; https://www.ft.com/content/683047ac-b85711e9-96bd-8e884d3ea203

5 This causal connection between government policies and improvements in living conditions is challenged by, e.g. Ansoms et al. (2010). Authors point to better weather creating rising agricultural productivity as one of the main reasons for improvements.

6 The report is based upon both quantitative data (survey) and qualitative data (interviews, group discussions, direct field observation and informal meetings collected across 300 villages in all 10 districts in 2017 (MINALOC, 2018a, b: 21-22).
} 
protection programmes, such as Girinka or food relief, were selected in an open and transparent manner (MINALOC 2018a, b, p. 51). Finally, and significantly for this paper, the survey found that decentralisation has not only been good for improving the participation of the majority in decision making but also that it has been very good for the marginalised: $97.2 \%$ of those surveyed were of the opinion that decentralisation has increased the voice of $\mathrm{HMPs}^{7}$ or Twa in their local communities.

Yet, our project data, examined in the following two sections, overwhelmingly find a high level of discontent among Twa interviewees about their lives. This discontent suggests that, despite the evidence that citizens are increasingly satisfied that decentralisation is achieving its goals, this satisfaction is not reaching all the way down to the most marginalised.

\section{Locating the Twa in Post-genocidal Rwanda}

National unity and the struggle against 'sectarianism' are the grounding principles of the regime's efforts to rebuild Rwanda after the total devastation of the 1994 genocide (NURC 2016, p. 59; Conner Doughty 2016). At the core of the NURC's unity programmes is the Ndi Umunyarwanda or 'I am Rwandan' programme. Launched in November 2013, the programme takes place at both community level and within institutions e.g. the police academy. What it aims to do, according to the NURC, is provide a forum in which communities can discuss issues relating to unity, reconciliation and development, and foster a sense of citizenship as a shared fate (NURC 2007: 112; Buckley-Zistel 2006)

The programme has faced substantial criticism. Much of this censure stems from the general criticism of national unity policies (see McLean Hilker 2009; Ingelaere 2010; Goodwin 2020). In relation to the Twa, the policy of national unity has been criticised for preventing the recognition of Twa as either a minority group or an indigenous people (Lewis 2000; Thomson 2009; Ndahinda 2011). In place of a status that accords the Twa formal recognition, official policy uses a catch-all label of 'Historically Marginalised Peoples' to capture the historical marginalisation of this group and their continuing socio-economic marginalisation. The inability to identify Twa as Twa under Rwanda law has made advocacy on behalf of this group to address their marginalisation difficult and the relationship between advocacy or representative groups and the government have often been fraught. It is this that has led some to suggest that the Twa are rendered invisible by this approach (e.g. Thomson 2011; Thomson 2009). This invisibility, it is further suggested, allows their marginalisation and the daily discrimination that they face to continue (Lewis 2000; Ntakirutimana and Collins 2017) and limits their participation in economic development.

\footnotetext{
7 Historically Marginalised Peoples: this is the only designation allowed by the Rwandan government to refer to Batwa as it does not reference ethnicity (see section "Locating the Twa in Post-genocidal Rwanda" below).
} 
Despite these structural difficulties, our project data suggests that national unity policies are beginning to work for the Twa (Goodwin 2020). That is, these policies play an important role in facilitating the feelings of inclusion by Twa in Rwandan society. A significant number of our interviewees reported that discrimination against them was a thing of the past, both in their daily relations with others and in their relationship to the authorities. A sizeable number, of mainly male interviewees, did state that daily acts of prejudice continue, such as name-calling or the refusal to accept hospitality; yet, even where it is reported that prejudice continues as a part of daily life, a clear pattern emerges that the situation is much better than it was. Many talked about a lack of discrimination and about how good relationships now were between Twa and their neighbours, irrespective of their background. The finding that prejudice against Twa is declining is corroborated by government polling, which suggests that prejudice against all groups is declining, and thus that the Twa opinions we heard are in line with a general societal trend. In the 2015 national Barometer, $87.7 \%$ of those polled stated that they now feel Rwandan above all other identities (NURC 2015, p. 47). Moreover, 93\% either strongly or fairly agreed that there is no discrimination "whatsoever" in social spaces, which marks a significant improvement since 2010 , when only $72.8 \%$ felt that there was no discrimination in social spaces (NURC 2015, p. 99). ${ }^{8}$

This improvement in relationships with neighbours was frequently attributed by Twa in our interviews to government policies and actions, and in particular to the messages embedded in the Ndi Umunyarwanda programme. One individual told us that the Ndi Umunyarwanda programme had given him confidence. He clearly felt that the identity of Rwandanness promised by the programme was open to him. Further, we collected evidence of Twa using the messages of the Ndi Umunyarwanda programme to challenge prejudice when they encountered it. This suggests that the message of a Rwandan unity is empowering some members of the Twa community to assert their place in Rwandan society (see also Williamson Sinalo 2018, who argues that Rwandicity is creating space for many to develop a post-colonial, posttrauma identity, albeit imperfectly).

Despite this evidence that many Twa appear to be benefiting from government policies of national unity and that some are able to use government unity narratives to create space for themselves as Rwandans, the data we collected was nonetheless dominated by strong feelings of discontent by our interviewees. The following section attempts to tease out make sense of these feelings of discontent despite the noted improvements in inclusion and in material well-being.

\footnotetext{
8 The Barometer polls are conducted every five years and 2015 is thus the most recent available as this paper is being written due to the disruption of the pandemic. It is important to note here that as ethnic data is not collected, we have no idea how many of the respondents were Batwa.
} 


\section{Including the Marginalised}

Our data supports the view of participants in the government's study that the position of Twa has indeed improved within society in the past decade, both in terms of participation and in material terms. We spoke to numerous individuals who felt well connected to government programmes and involved in local authority decision making. A gentleman in Nyabihu district told us:

We do manifest our opinions. I sometimes take time to go to the sector, meet the person in charge of social affairs and share my opinions and those of fellow HMPs in Gahini sector with them. (Nyabihu district)

Similarly, a woman in Rusizi district told us that not only were things in her sector so well run that discrimination is a thing of the past, but that Twa could aspire to local leadership themselves.

Moreover, interviewees told us of their inclusion in government programmes and what that meant to them. A man in Nyamasheke district explained to us the empowering effect of inclusion:

We have been beneficiaries of projects that assisted us on securing things like those doors, windows and stools. One of the good things that I want to do is to improve this house so that it can be in a far better shape. ... I want to be able to secure electricity for myself so that I do not have to rely on others.

Having been the beneficiary of a house, he was determined to improve it and viewed the assistance that he had received as a springboard to continuing improvements in his life. This feeling of being included, of being connected to others-more formally, of being worthy of equal concern by those in authority - stemmed from participation in government programmes. As a man in Gatsibo district made explicit:

These programs give me hope of a better tomorrow. They make me not feel lonely because I feel connected with others in being part of these aspirations. When you feel connected with others, you feel less lonely because you are aware of what is going on around you.

The importance of feeling included, and the relationship between inclusion and material resources, is clear.

Yet, those who feel hopeful and well connected were not the majority of those with whom we spoke. While the initial project hypothesis was that feelings of marginalisation are due to discriminatory treatment, analysis of the data suggests a more complex picture.

\section{Feelings of Progress are Relative}

A woman from Nyaruguru district repeatedly returned to the theme of unfair treatment by local authorities throughout her interview. For example, she told us: 
In Rusenge sector, others received financial assistance. If I was to get 50,000 RWF, I would no longer need to do petty labour for others. What I get from my petty labour is not enough to cover my needs (soap, salt etc.). It is very difficult.

What this woman is saying is that she is treated differently to others. She did not specify who those others were, but she did not suggest that they were non-HMPs or had benefitted for an unfair reason. This fits with many of the complaints that we heard. The sense of unfairness that was most often articulated stemmed from a perceived unfair distribution of goods that was either territorial (in another place) or personal (not them). The majority of those who complained did not attribute the unfairness to group identity i.e. because they were Twa. For example, while individuals complained that they had missed out, they noted that members of their direct family had benefitted. The following from a gentleman in Nyamasheke district was typical:

Regarding the Girinka programme, you remember the young man we were talking with? He is the son of my older brother. He received a cow. They also recently gave one to my son too, but it died but it left behind a calf. There people were given cows, including my immediate neighbour. Personally, I did not benefit.

The same effect was felt when the beneficiaries were outside the immediate family or neighbourhood. We were often told that they and their village had not benefitted but that others, in other villages, had. For example:

The problem that we have is that other HMPs are provided with health insurance but that is not the case here in Kayonza district.

Another female interviewee in Nyaruguru district told us something similar:

In other settlements, like Viro, all HMPs were assisted but in our settlement, no-one of us was helped except that one person.

The unfavourable treatment that is being complained of was thus not necessarily attributed to being Twa or HMP, but there was a clear sense that they were being treated unfairly.

While the Twa are not directly targeted in terms of service delivery as Twa, i.e. they are not targeted as a group, they are most likely to fall within the poorest categories and are therefore indirectly prioritised for redistribution efforts. The available evidence suggests that decentralisation policies have been successful for the majority of Rwandans in improving their material well-being, and the poorest Rwandans, the Twa among them, have benefitted most. So how should we understand their complaints? 
Rapid economic growth in Rwanda has been accompanied by improvements to living standards for the poorest. However, inequality remains a large problem. Although the Gini co-efficient has declined slightly over the past 15 years, it remains high compared to neighbouring countries (McKay and Verpoorten 2016). ${ }^{9}$ Moreover, McKay and Verpoorten found in their study of Rwandan inequality that while happiness is weakly correlated with income, it is "strongly correlated with relative income mobility (both measured and self-reported)" (McKay and Verpoorten 2016, p. 129). That is, even those who were significantly better off than they had been registered as unhappy where others around them were progressing more quickly or at the same level. This leads McKay and Verpoorten to conclude that "[p]rogress in terms of levels of monetary and non-monetary indicators does not necessarily mean that people feel better off, certainly when others are also making progress, at a faster rate." (McKay and Verpoorten 2016, p. 130). The feelings of unfairness that we registered were similarly based on a comparison with others. Although our interviewees acknowledged for the most part that they were benefitting from government programmes, they appeared to feel that others were benefiting more or at least the same; that is, their situation relative to others was not improving. This reading of the data suggests that better resource distribution as a result of decentralisation is not enough in itself to decrease levels of inequality or the resentment that accompanies it, even where individuals acknowledge that they are better off than they were.

\section{Poor Communication}

A second element of unfairness that we discerned from our data relates to the question of the timing of resource distribution. Individuals frequently told us that they had been told that they will benefit, perhaps from a shelter or a cow, but that they were still waiting. A man from Kicukiro district told us that he and his family were waiting for a shelter:

We hope, even if our hopes are at times discouraged because, look, it has been 8 years and nothing happens.

Similarly, a man from Kayonza district made clear what waiting does to you when you do not understand why you are waiting or for how long you will be expected to wait:

[t]here was once a project in which we were not included but instead replaced by others. They took lists, replaced us with others and that is the end of the story. We are still waiting, and our names are on record at the district, cell and at the sector but of course we have lost hope.

\footnotetext{
9 The World Bank suggested, in a March 2021 update, that Rwanda's Gini co-efficient stood at 0.43. Kenya and Tanzania stood at 0.41 and 0.4 respectively. See https://www.worldbank.org/en/country/ rwanda/overview\#1.
} 
These feelings of unfairness are not a result of exclusion from government largesse, or of discrimination, but a result of the feeling that promises had been unfulfilled while others benefitted, such as that clearly expressed by a woman in Rwamagana district:

In a local meeting, I raised my problem of my collapsed house and they said that they will take care of it. And my neighbour here - an old woman - they said that they will rebuild her house. But until now, nothing was done.

An additional explanation for our findings of continued discontent despite an overall increase in material well-being is therefore that our interviewees do not understand how the decisions about distribution are made. They do not understand the who, the what and, equally crucially, the when: that is, who gets what, in what order and how long it will take. This lack of understanding about how decisions are taken and how long the wait might be leads to frustration, to feelings of unfairness and, not infrequently, to despair. While many interviewees reported that they saw their local leaders regularly and some had the opportunity to speak with them, our findings suggest that visibility and accessibility are not sufficient to generate local good governance without effective communication.

The issue of poor communication is recognised by the government's review of its decentralisation policies. That report identifies part of this communication problem as involving difficulties in co-ordinating information between district, sector and village levels, whereby local leaders closest to the ground are themselves not sufficiently well informed (MINALOC 2018a, b, pp. 71-72). It further highlights the lack of human capacity at the cell level, noting that cell offices are still inadequately staffed, underequipped and under-funded. Another aspect of poor communication noted by the review and backed up by our data relates to the continuation of top-down practices of authority. Constituents are rarely spoken to as equals, something that we witnessed in interviews with local leaders at all levels in how they spoke of Twa but also in how they spoke to the Twa participants during our group feedback sessions. As an elderly lady in Rwamagana district told us [y]ou call a local leader, instead of providing you with a solution, he or she despises you as if he didn't understand you. This dismissive attitude of leaders is given considerable attention in the decentralisation review: the report notes the need to provide local leaders with the skills "for effective engagement of all citizens" (MINALOC, 2018a, b, p. 61). It is worth noting that our data does not specifically suggest that the dismissive attitude of many local leaders is connected to ethnicity; it may be that what we witnessed is a general attitude towards poor constituents. Nonetheless, as we discuss in the next section, around a third of our interviewees did attribute an ethnic bias to their unsatisfactory interactions with local authorities.

A yet other part of the communication failure that we noted, although it is not covered by the review, is the ability of the severely poor to attend village meetings. Many of our interviewees told us that they could not always attend the meetings because they were out looking for clay, firewood or food. As the village meeting is the main source of information and the place at which distributive decisions are taken, as well as the main forum for citizen participation, an inability to attend matters for inclusion. Improving communication with the poorest citizens is therefore likely to need a more 
flexible approach to information-sharing and participation, one that can accommodate the survival needs of the most marginalised.

If a practice of downward accountability of local leaders is to take hold, and inclusion and citizen empowerment are to reach down to the most marginalised, local leaders need to take seriously their accountability to their constituents: listening, explaining and responding. This is more than simply informing. Moreover, they need to do so in a communication style and on a timetable that is adapted to the needs of their constituents.

\section{Discontent Leading to Feelings of Exclusion}

The feelings of unfairness and that belief no one is listening that we heard are important not only for the individuals concerned but for society more broadly. While it is worth repeating that the majority of those that we spoke to did not attribute the unfairness that they experienced to their group identity, a significant minority did. A woman that we spoke to in Nyaruguru district told us:

[L]ocal leaders here do not take our problems seriously. They dismiss them as Batwa problems. They do not welcome us the same way they welcome non-Batwa. They do not render justice to us as they do to others.

The belief among our some of our interviewees that they are denied access to material resources, such as Girinka, VUP or medical insurance, because they are Twa has grave consequences for social cohesion. A woman in Rusizi district articulated the same sentiment in even starker terms:

They don't take sticks and beat us, nor do they abuse us with their tongues. But if we are not benefiting from programmes like others, it is a kind of violence against us.

To be clear, the same individuals that made these comments also acknowledged that they had benefitted from government programmes, whether in receiving cash hand-outs or other forms of assistance. Yet, they did not feel included. In the context of their historical marginalisation, it is easy for them to associate their exclusion with being identified as Twa. This sense of not being included because one is Twa gave rise in some of our interviewees to calls for representation. A female interviewee from Muhanga District, when asked whether she felt able to give her opinions in local meetings (village or sector), replied:

We don't know how to give our opinions. We are supposed to give them at meetings. But we don't have anyone who can advocate for us. If we do that ourselves, they don't understand us, so it [making our voices heard] is a challenge. We need someone who can speak for us. The fact is that we don't have any one of our HMPs involved in the leadership of our village. It would be easier for us to tell such a person our problems, but from village up to district level, no one of us is involved in leadership, so it is as if we are rejected. 
The conviction that they are not able to participate in meetings in a way that works for them fuels the belief that mediated representation is necessary and that this representation needs to be from the same community. Awakening this belief that participation needs to take place via group-based identification undermines the message of national unity and the progress towards the social inclusion of the Batwa through the Ndi Umunyarwanda programme. As such, it undermines the role of decentralisation in achieving social stability.

At the same time, we also found that local communities are ready and able to engage in the practice of local governance, including holding local officials accountable. Despite often being isolated in rural areas, our interviewees were nonetheless well informed about what was happening in other places. A woman in Rusizi district, for example, was apparently in possession of the necessary information in order to be able to make the following complaint:

Other people were provided with housing. In Ruharambuga, people were given new shelters; in Nyakabuye, the same. Even closer to here, in Nyamagana, in Nyakarenzo, people benefited. But here in Gihundwe, nothing was done, especially in this village of ours of Kanombe.

While we were not able to verify this statement in its entirety, interviewees in Nyakarenzo did confirm that they had been given a plot of land and a house that included a kitchen and toilet, as well as 45 iron sheets for the roof. This suggests that information about the distribution of public resources travels. Further, our interviewees were, on the whole, very well informed about the various government programmes, in the sense of knowing how they could benefit from them and of knowing who had benefited from them in their local community.

In addition to being generally well informed about resource distribution, our interviewees were interested in how decisions on distribution were taken beyond their own self-interest and wanted to contribute ideas on how that distribution took place. A different interviewee also from Rusizi district told us the following:

Recently people received money under the Ubudehe program. As you can see, this settlement is big. The money amounted to 280,000Frws. For Kabayego South, they used 220,000 for works on the road. The remaining 60,000Frws were still given to someone in that Southern part. I raised the question [at a meeting], why the 60,000 had not been given to an HMP from Northern Kabayego to use for some income generating project at the market whereby he would pay back the loan to the Settlement or Cell. They replied that the person who was selected was the right person to receive the money. I asked why not us. I received no reply. They simply said that the money was already allocated, and we had to wait for future possibilities.

This statement shows that this woman had knowledge of local decision making and an understanding of the choices available. Moreover, she had ideas to contribute and wanted to do so. While this woman's detailed account was perhaps not typical of our interviewees, many of the people that we spoke with wanted to play an active part in local decision making. The frequent complaints made to our interviewers of not 
being heard suggest precisely a desire to have a say in decision making as well as an ability to do so. Any barrier to creating inclusive downward accountability does not appear, therefore, to come from the citizens themselves.

\section{Achieving Inclusion Through Decentralisation?}

Our analysis suggests that 15 years of decentralisation, although it does appear to have empowered many ordinary citizens to be involved in local decision making, has not yet done so for everyone. Those who were marginalised remain so. This is a group larger than the Twa. The government's own data found that while $86 \%$ of those surveyed confirmed that they regularly participate in village meetings, only $44.6 \%$ stated that they actively contributed ideas in meetings and only $66 \%$ of those surveyed felt that their opinions were taken into account in local decision making (MINALOC 2018a, b, pp. 29-30). A sizeable 3\% felt strongly that beneficiaries of the social protection programmes were not selected in an open and transparent manner. These figures suggest that although the Rwanda government is justified in claiming significant success in changing the relationship between authorities and the governed, there is still work to be done (see also Protik et al, 2018). The Twa are not alone in not feeling fully included.

The feelings of unfairness that we witnessed reflect the limitations in implementation of the third phase of decentralisation: that of creating downward accountability. The Rwandan model has been, in comparison with decentralisation outcomes elsewhere in Africa, remarkably successful in avoiding the problem of local elite capture (see Lund 2006). Corruption levels remain impressively low throughout the levels of governance (World Bank 2020). This is widely attributed to the annual performance contracts (Imihigo) that are signed between district leaders and the President, and that are monitored and enforced by the central level. These contracts are a form of planning, as well as of monitoring and enforcement. As such, they combine traditional Rwandan leadership philosophy with new public management techniques (Kamuzinzi 2016). Despite their hybrid form, however, the focus on results creates strong external control and thus a strong accountability upwards to the central level. The creation of imihigo- the precise formulation of targets with quantitative indicators, alongside the very ambitious nature of the targets-in the second phase of decentralisation put the focus of local governance on upward accountability. This is reflected in the government's own findings that local communities were more likely to attempt to hold local authorities to account by complaining to the central government rather than by engaging with them directly (MINALOC 2018a, b, p. 49).

Further, the contracts create a harsh environment for local leaders. The stress that the imihigo create for these officials is well captured by the creation of a new verb in Kinyarwanda: guteknica, which Chemouni translates as 'to technicate' (Chemouni 2014 , p. 250). The strict process of imihigo has thus resulted in a technical form of government, in which meeting targets necessarily takes priority over explaining oneself to local communities. As Chemouni has noted, the result has been the creation 
of a depoliticised, technocratic elite at the local level that is deeply loyal to the centre (Chemouni 2014, p. 253; see also Hasselskog and Schierenbeck 2015). While this approach has been very successful in ensuring a results-orientated bureaucracy_visible in the lack of corruption and enviable results in service delivery- the approach is hampering the implementation of bottom-up accountability. Taking the time to engage with all citizens such that they are able to understand decision making and participate in it has been less important to leaders to date than satisfying the demands of central government (also Gaynor 2014).

At the same time, decentralisation via its regular community meetings has created the infrastructure for community participation. To overcome the difficulties of including the most marginalised, a chain of inclusive community participation needs to be created from the umudugudu, to the cell, to the sector, and up to the district level. This requires, as the government itself notes, a change to the incentive structure but also a shift in focus from district to the village or umudugudu level. As this is where citizens have most contact with authority and it is where they gain their information, village leaders need to be better resourced and skilled to ensure participation and inclusion. The government's review indicates that they are well aware of this issue and are making plans to address it.

However, a lack of active participation is not the only cause of the reported feelings of unfairness among the Twa. Similarly to McKay and Verpoorten's analysis, our data suggests that inequality is an important factor in how included our interviewees felt. Feeling included is a combination of voice, redress and access to material resources. But it is more than this: this paper provides evidence to suggest that access to resources will not increase feelings of well-being and of inclusion if others are progressing at the same pace or faster, particularly in a context where inequality is already high. The gap to the rest of society is an important element in creating the feelings of unfairness in how resources are distributed and in exclusion from decision making. Our findings suggest that pro-poor programming, even when combined with committed decentralisation efforts, will struggle to achieve inclusion if inequality remains. Yet, in contrast to the recognition of the problem of a too-strong focus on accountability to central government and of the need to improve the communication skills and resources of local leaders (MINALOC 2018a, b), the issue of equality is addressed in neither the government's review of decentralisation nor in the Vision 2050 plan for continuing national development. Vision 2050 sets new targets for gender equality and recognises the need to continue to work on the inclusion of youth and people with disabilities (MINECOFIN 2015, p. 32). But there is no mention in the plan of economic inequality or of the need for explicit efforts to include the poorest by closing the gap to the rest of society. Instead, the focus on inequality of those who have been historically marginalised is solely on combatting discrimination and social exclusion via a focus on national unity.

The sense of unfairness and the hopelessness that exclusion can engender also undermines the messages of self-reliance and dignity that form the basis of Rwanda's development vision (MINECOFIN 2015). Feelings of hopelessness, encouraged by a lack of understanding of how decisions are made and a belief that no one is listening, undermine confidence in themselves, trust in the local authorities and ultimately pushes people into a passive stance towards improving their lives. This 
was visible in the number of interviewees who told us that they could do nothing until they received more help. Thus, while a significant number of our interviewees told us that they find the doctrine of self-reliance empowering, for that feeling to be translated into actual empowerment, individuals need to believe that there is a way out of their economic marginalisation, in the same way that they have begun to feel socially included as Rwandans.

Finally, the question of the extent to which the feelings of discontent our project data identified among our Twa interviewees is rooted in ethnic bias is a complex one. Certainly discrimination continues between private persons, although the evidence is that it is declining, and Twa feel more included in society than they did in the past. It is also possible that public officials do discriminate against Twa individuals but we cannot conclude that from our data; their attitude, where less than positive, could also be attributed to a failure to take their (poorest) constituents seriously, whether as a result of attitude or of a lack of means and skills to do otherwise. In listening closely to what our participants told us about their lives, the common complaint of differential treatment in the distribution of resources or of others being treated better than them was not grounded in ethnic difference. The complaint made by the majority of interviewees was not that they did not benefit as much from government programmes as others because they were Twa. However, where our participants felt that they were dismissed or ignored, some made sense of their treatment by reference to their marginalised position as Twa; that is, even if the inequality that they experience is the result of a failure to overcome marginalisation in the past, it can easily be attributed to ethnic discrimination in the present. This nuance is important. And it matters, as this paper has tried to suggest, because of the risk that it undermines social stability in a country that continues to deal with the aftermath of horrendous ethnic-based violence.

\section{Conclusion}

Our data suggests that the most marginalised in Rwanda continue to feel excluded. This occurs against a background of impressive pro-poor service delivery and a serious commitment to decentralising governance. Despite successes in beginning to address legacies of social marginalisation and discrimination through programmes such as Ndi Umunyarwanda and the significant improvements in living standards, the Twa remain among the poorest of the poor, relatively seen. Rwanda's economic growth in the past 20 years has lifted everyone, yet has left the majority of Twa almost precisely as far behind.

These findings on the impact of decentralisation on feelings of inclusion help to nuance our understanding of the relationship between economic growth and inclusion. They suggest that even where individuals acknowledge that their living standards have improved, where material differences continue to exist, the poorest may continue to feel excluded. While inclusion can certainly be improved by decentralisation and, even further, by more effective communication between local leaders and 
marginalised groups, economic inequality is likely to continue to form a barrier to inclusive development that even strong, pro-poor institutions cannot surmount (Dekker and Pouw 2021).

In its detailed and self-critical review of progress towards achieving the goals of decentralisation, the Rwandan government acknowledges that there is room for improvement. The report's emphasis on improving communication with all Rwanda's citizens and on re-balancing upward and downward accountability in favour of the latter will go someway to addressing the feelings of exclusion that we encountered. However, the apparent exclusion of the problem of economic inequality in new development planning or in the continuing process of decentralisation is concerning. Where perceptions of economic unfairness can be attributed to membership in a group based on historical experience, the failure to tackle inequality by putting even more focus on levelling up the poorest threatens to undermine progress towards social inclusion. In Rwanda, it also threatens the progress towards national unity and stability that decentralisation was designed to beget.

\section{Declarations}

Conflict of interest On behalf of all authors, the corresponding author states that there is no conflict of interest.

Open Access This article is licensed under a Creative Commons Attribution 4.0 International License, which permits use, sharing, adaptation, distribution and reproduction in any medium or format, as long as you give appropriate credit to the original author(s) and the source, provide a link to the Creative Commons licence, and indicate if changes were made. The images or other third party material in this article are included in the article's Creative Commons licence, unless indicated otherwise in a credit line to the material. If material is not included in the article's Creative Commons licence and your intended use is not permitted by statutory regulation or exceeds the permitted use, you will need to obtain permission directly from the copyright holder. To view a copy of this licence, visit http://creativecommons.org/licen ses/by/4.0/.

\section{References}

Ansoms, A. 2009. Re-engineering rural society: The visions and ambitions of the Rwandan elite. African Affairs 108: 289-309.

Ansoms, A., A. Verdoodt, and E. Van Ranst. 2010. A green revolution for rural Rwanda: Reconciling production growth with small-scale risk management. A paper prepared for the 10 years of war against poverty conference, 8-10 September, Manchester, UK.

Bentzon, A.W., A. Hellum, and J. Stewart (Eds.). 1998. Pursuing grounded theory in law : South-Northexperiences in developing women's law. Avondale, Harare, Zimbabwe: Mond Books.

Booth, D., and D.R. Cammack. 2013. Governance for development in Africa: Solving collective action problems. London: Zed Books.

Buckley-Zistel, S. 2006. Dividing and uniting: The use of citizenship discourses in conflict and reconciliation in Rwanda. Global Society 20: 101-113.

Chemouni, B. 2014. Explaining the design of the Rwanda decentralization: Elite vulnerability and the territorial repatriation of power. Journal of East African Studies 8 (2): 246-262.

Chemouni, B. 2016. Taking stock of Rwanda's decentralisation: Changing local governance in a postconflict environment. Third World Thematics: A TWQ Journal 1 (6): 763-778. 
Conner Doughty, K. 2016. Remediation in Rwanda. Grassroots legal forums. Philadelphia: University of Pennsylvania Press.

Dekker, M. and Pouw, N. (2021) Introduction to the special issue: Policies for Inclusive Development in Africa.

Dietz, T. 2012. Participatory assessment of development in Africa. In Local governance and poverty in developing nations, ed. I. Baud and N. Pouw, 216-240. New York: Routledge.

Dietz, T., R. Bymolt, A. Bélemvire, K. van der Geest, D. de Groot, D. Millar, F. Obeng, N. Pouw, W. Rijneveld, and F. Zaal. 2013. PADev guidebook. Participatory assessment of development. Amsterdam: KIT Publishers.

Gaventa, J. (2005) Reflections on the uses of the 'power cube' approach for analyzing the spaces, places and dynamics of civil society participation and engagement. CFP evaluation series 2003-2006: no. 4.

Gaynor, N. 2014. 'A nation in a hurry': The costs of local governance reforms in Rwanda. Review of African Political Economy 41 (1): 49-63.

Goodwin, M.E.A. 2020. Becoming Rwandan? The impact of two decades of unity policies on the Batwa. KAOW Bulletin Des Séances/mededelingen Der Zittingen 63: 187-208.

Gough, I., and J.A. McGregor. 2007. Wellbeing in Developing Countries: From theory to research. Cambridge: Cambridge University Press.

Gupta, J., N.R.W. Pouw, and M.A.F. Ros-Tonen. 2015. Towards an elaborated theory of inclusive development. Journal of Development Research 27 (4): 541-559.

Hammett, D., C. Twyman, and M. Graham. 2015. Research and fieldwork in development. Abingdon, UK:Routledge.

Hasselskog, M., and I. Schierenbeck. 2015. National policy in local practice: The case of Rwanda. Human Rights Quarterly 36 (5): 950-966.

ICERD. 2016. Concluding observations on the eighteenth to twentieth periodic reports of Rwanda, CERD/C/RWA/CO/18-20, 10 June 2016.

Ingelaere, B. 2010. Peasants, power and ethnicity: A bottom-up perspective on Rwanda's political transition. African Affairs 109: 273-292.

Kamuzinzi, M. 2016. Imihigo: A hybrid model associating traditional and modern logics in public policy implementation in Rwanda. International Journal of African Renaissance Studies - Multi-, Interand Transdisciplinarity 11 (1): 123-141.

Kimonyo, J.-P. 2015. Rwanda's popular genocide. A perfect storm. Boulder: Lynne Rienner Publishers.

Lewis, J. 2000. The Batwa pygmies of the Great Lakes region. London: Minority Rights Group Report.

Lund, C. 2006. Twilight Institutions: Public Authority and Local Politics in Africa. Development and Change 37 (4): 685-705.

McDoom, O.S. 2021. The path to genocide in Rwanda. Security, opportunity and authority in an ethnocratic state. Cambridge: Cambridge University Press.

McKay, A., and M. Verpoorten. 2016. Growth, poverty reduction, and inequality in Rwanda. In Growth and poverty in Sub-Saharan Africa, ed. C. Arndt, A. McKay, and F. Tarp, 112-136. Oxford: Oxford University Press.

McLean Hilker, L. 2009. Everyday ethnicities: Identity and reconciliation among Rwandan youth. Journal of Genocide Research 11: 81-100.

MINALOC. 2001. National decentralization policy. Kigali: Ministry of Local Government and Social Affairs, Republic of Rwanda.

MINALOC. 2004. Rwanda five-year decentralization implementation program. Kigali: Ministry of Local Government, Republic of Rwanda.

MINALOC. 2011. Decentralization implementation plan 2011-2015. Kigali: Ministry of Local Government, Republic of Rwanda.

MINALOC. 2018a. Assessment of the impact of decentralisation policy implementation in Rwanda (2001-2017). Kigali: Ministry of Local Government, Republic of Rwanda.

MINALOC. 2018b. Governance and decentralization sector strategic plan (2018/19 - 2023/24). Kigali: Ministry of Local Government, Republic of Rwanda.

MINECOFIN. 2015. Vision 2050. Kigali: Ministry of Finance and Economic Planning, Republic of Rwanda.

Ndahinda, F.M. 2011. Indigenousness in Africa: A contested legal framework for empowerment of 'marginalized' communities. The Hague: Springer/T.M.C. Asser Press. 
Ntakirutimana, R. and B. Collins. 2017. 'Am I Twa or HMP?': Examining the 'historically marginalized people' label and the acculturation of the Twa in Rwanda'. Aegis Working Paper PB 005: September 2017.

NURC. 2004. The road towards unity and reconciliation. Ten years after (1994-2004). Kigali: National Unity and Reconciliation Commission.

NURC. 2007. The national policy on unity and reconciliation. Kigali: National Unity and Reconciliation Commission.

NURC. 2009. Strategic Plan 2009-2012. Kigali: National Unity and Reconciliation.

NURC. 2015. Rwanda reconciliation barometer. Kigali: National Unity and Reconciliation Commission.

NURC. 2016. Unity and reconciliation process in Rwanda. Kigali: National Unity and Reconciliation Commission.

Protik, A.E., I. Nichols-Barrer, J. Berman, and M. Sloan. 2018. Bridging the information gap between citizens and local governments: Evidence from a civic participation strengthening programme in Rwanda. World Development 108: 145-156.

Reinders, S., M. Dekker, F. van Kestern, and L. Oudenhuijsen. 2019. Inclusive development in Africa. INCLUDE: March 2019.

Ribot, J.C. 2002. African decentralization. Local actors, powers and accountability, UNRISD Paper no. 8.

Rodrik, D. 2007. One economics. Many recipes: Globalization, institutions and economic growth. Princeton, NJ: Princeton University Press.

Taylor, C.C. 2011. Molders of mud: Ethnogenesis and Rwanda's Twa. Ethnos 76: 183-208.

Thomson, S. 2009. Ethnic Twa and Rwandan national unity and reconciliation policy. Peace Review 21: 313-320.

Thomson, S. 2011. Whispering truth to power: Everyday resistance to reconciliation in postgenocide Rwanda. African Affairs 110: 439-456.

Vansina, J. 2001. Le Rwanda ancien: Le royaume nyiginya. Paris: Karthala Editions.

VeneKlasen, L., and V. Miller. 2002. A new weave of power, people and politics: The action guide for advocacy and citizen participation. Rugby: Practical Action Publishing.

Williamson Sinalo, C. 2018. Rwanda After Genocide Gender, Identity and Post-Traumatic Growth. Cambridge: Cambridge University Press.

Wolff, J., and A. de-Shalit. 2007. Disadvantage. Oxford: Oxford University Press.

World Bank. 2020. Rwanda's anti-corruption experience: Actions, accomplishments, and lessons. Report No. AC29873. Washington, DC: World Bank.

Publisher's Note Springer Nature remains neutral with regard to jurisdictional claims in published maps and institutional affiliations.

Morag Goodwin is Professor of Global Law and Development, Tilburg University; m.e.a.goodwin@tilburguniversity.edu. The findings on which this article is based are the product of a four-year research project, conducted jointly by the Communauté des Potiers du Rwanda /Rwandese Community of Potters (COPORWA), the Institute of Research and Dialogue for Peace (IRDP) and Tilburg University. This project was part of the research agenda of the INCLUDE Knowledge Platform Development Policies and funded by the Dutch Ministry of Foreign Affairs through NWO-WOTRO. Their support is gratefully acknowledged. My thanks, too, to the two anonymous reviewers for their helpful suggestions and feedback; any errors remain, of course, my own. 